О. О. Волобуєва

\title{
ФУНКЦІОНУВАННЯ НЕЕЛЕМЕНТАРНИХ СКЛАДНОПІДРЯДНИХ РЕЧЕНЬ ІЗ ПІДРЯДНИМ КОМПОНЕНТОМ ПРИЧИНИ В УКРАЇНСЬКІЙ ХУДОЖНІЙ ПРОЗІ ПОЧАТКУ ХХІ ст.
}

\footnotetext{
Волобуєва О. О. Функціонування неелементарних складнопідрядних речень із підрядним компонентом причини в українській художній прозі початку XXI ст.

У статті уперше у вітчизняній синтаксичній науці зроблено спробу визначити особливості функціонування неелементарних складнопідрядних речень із підрядним компонентом причини в прозових творах сучасних українських авторів, виокремлено їх структурно-семантичні і смислові різновиди.

Ключові слова: неелементарні складнопідрядні речення з підрядним компонентом причини, структурно-семантична організація речення, смислова модель речення, засіб художньої оповіді.

Волобуева Е. А. Функционирование неэлементарных сложноподчиненных предложений с придаточным компонентом причины в украинской художественной прозе начала XXI в.

В статье впервые в отечественной синтаксической науке сделана попытка определить особенности функционирования неэлементарных сложноподчиненных предложений с придаточным компонентом причины в прозаических произведениях современных украинских авторов, выделены их структурно-семантические и смысловые разновидности.

Ключевые слова: неэлементарные сложноподчиненные предложения с придаточным компонентом причины, структурно-семантическая организация предложения, смысловая модель предложения, средство художественного повествования.

Volobuyeva O.O. Functioning of non-elementary compound sentences with cause-subordinate clause in the Ukrainian fiction of the early $21^{\text {st }}$ century.

The article deals with the peculiarities of functioning of non-elementary compound sentences with cause-subordinate clause in the prose literary works of modern Ukrainian writers; their structural-semantic and notional types are distinguished.

Key words: non-elementary compound sentences with cause-subordinate clause, structural-semantic organization of sentence, notional model of sentence, means of narration.
}

Складнопідрядні речення з кількома підрядними вже тривалий час перебувають у колі зацікавлень російських і українських мовознавців (В. Бєлошапкова, І. Василенко, І. Вихованець, Н. Ганцовська, В. Казмін, Г. Калашникова, І. Кучеренко, М. Поспєлов, Г. Уханов, К. Шульжук). Були проведені грунтовні дослідження щодо виявлення особливостей реалізації

() О. О. Волобуєва, 2011. 
складнопідрядних речень 3 однорідною супідрядністю (І. Василенко, Т. Шкарбан), з неоднорідною супідрядністю (І. Василенко) і з послідовною підрядністю (О. Кузьмич, В. Шитов). Донедавна складнопідрядні речення 3 кількома підрядними дослідники переважно розглядали разом iз складнопідрядними реченнями елементарної будови. Проте, на думку сучасних синтаксистів (І. Вихованець, О. Кузьмич, Т. Шкарбан, К. Шульжук), «ці структури мають специфічні особливості» [10, с. 303] i повинні досліджуватися як поліпредикативні складнопідрядні речення. Оскільки в мовознавчій науці немає єдиної назви і визначення подібних поліпредикативних синтаксичних утворень, i такі синтаксичні структури називали по-різному: складнопідрядні багатокомпонентні речення [4, с. 340; 5, с. 290; 10, с. 303], кількакомпонентні складнопідрядні речення [5, с. 290], неелементарні складнопідрядні речення [4, с. 340], багаточленні складнопідрядні речення [8, с. 433], у своєму дослідженні ми кваліфікуємо конструкції аналізованого різновиду як неелементарні складнопідрядні речення.

До цього часу були проаналізовані лише багатокомпонентні складнопідрядні речення з різнотипними смисловими відношеннями, що склалися між їх предикативними частинами, й обійдені увагою складнопідрядні речення неелементарної будови, між компонентами яких спостерігаються однотипні смислові відношення, зокрема відношення причини. На нашу думку, функціонування поліпредикативних складнопідрядних речень із причиновими відношеннями набуває особливої актуальності, коли мова йде про їх реалізацію в художньому тексті. Недостатнє висвітлення цього питання на сторінках вітчизняних наукових видань зумовило обрання теми нашої статті, актуальність якої підтверджує викладене.

Мета цієї розвідки - дослідити особливості реалізації неелементарних складнопідрядних речень із підрядним компонентом причини в українській художній прозі початку XXI ст. Для цього необхідно визначити риси структурно-семантичної організації аналізованих конструкцій, виділити моделі досліджуваних речень за смисловим наповненням кожного складника, схарактеризувати особливості стилістичного використання названих синтаксичних утворень.

Із метою одержання найбільш об'єктивних даних, матеріал для дослідження добирався 3 відмінних за жанрово-стильовими ознаками прозових творів: філософська проза (повісті Софії Андрухович «Літо Мілени», «Старі люди»), історична проза (повість Насті Байдаченко «Перший гріх Ізабелли»), реалістична проза (роман Марії Матіос «Нація», роман Ліни Костенко «Записки українського самашедшего»).

Спостереження показали, що в опрацьованих повістях і романах більш чисельно представлені складнопідрядні речення неелементарної будови, між предикативними частинами яких склалися різнотипні семантичні відношення, у тому числі і причинові, як-от: I щ̧е кажуть, щ⿻о 
осику не можна брати на будівництво дому, бо від хвороб уся родина тремтітиме день і ніч, як це дерево (М. Матіос); На останньому розлученні в суді дід привселюдно зарікався ніколи не зустрічатися 3 бабцею, бо вони повні антиподи, хоча обоє й однаково прагнуть бути в цеентрі уваги, $i$ тому за жодних умов не зможуть жити разом (С. Андрухович), а неелементарні складнопідрядні речення 3 підрядним компонентом причини не вирізняються активним поширенням, проте це не применшує їхньої цінності для лінгвістичного дослідження.

Результати аналізу структурно-семантичної організації досліджуваних складних речень засвідчили, що у прозових творах сучасних авторів уживаються неелементарні складнопідрядні речення 3 підрядним компонентом причини такого зразка:

a) трикомпонентні 3 однорідною супідрядністю, де підрядні компоненти причини обгрунтовують групу присудка в головному складнику: Після циих одкровень батькова дружина заборонила вмикати телевізор і призначила йому курс лікування, ${ }^{l}$ бо у нього піднявся тиск ${ }^{2} i$ посилилась аритмія ${ }^{3}$ (Л. Костенко) (тут і далі цифра-індекс позначає номер предикативної частини в реченні); сполучник підрядності вживається тільки перед першим підрядним компонентом, перед другим підрядним сполучник факультативний, що є характерною рисою для речень такого типу [10, с. 320];

б) П’ятикомпонентні 3 однорідною супідрядністю: Я шкодувала себе, ${ }^{1}$ бо мала на вказівному пальиі ранку, бо відчувала біль, ${ }^{3}$ бо в мене текла червона кров, ${ }^{4}$ бо я жила ${ }^{5}$ (С. Андрухович); сполучник підрядності вживається перед кожним підрядним компонентом.

Причинові відношення, відношення причинового пояснення чи обгрунтування, як зазначають дослідники синтаксису складного речення [9, с. 63], встановлюються в синтаксичних конструкціях відповідно до події чи факту, з якою вони пов'язані. 3-поміж таких структур виділяють об’єктивно-пізнавальні речення (причинові відношення, які стосуються подій і явищ об'єктивної дійсності) й «особистісні» речення (відношення в яких пояснюють чи аргументують дії або стан людини).

Під час дослідження 3'ясовано, що в художніх творах сучасних прозаїків уживаються неелементарні складнопідрядні речення 3 підрядним компонентом причини тільки «особистісного» характеру.

Зібрані і проаналізовані дані дозволили виокремити такі смислові моделі особистісних неелементарних складнопідрядних речень із підрядним компонентом причини:

а) емоційний стан - характеристика обставин, які стали причиною такого емоційного стану (в усіх підрядних частинах): Cmpax $i$ неспокій поперемінно сковував людей, ${ }^{l}$ бо прийшов $i$ пішов твердий на вдачу москалик, ${ }^{2}$ прийшов і пішов звиклий до муштри й дисциипліни румун, знову вступивши край швидкому до дій москалеві ${ }^{3}$ (М. Матіос);

๑ О. О. Волобуєва, 2011. 
б) психічний стан - фізичний стан цієї ж особи (в усіх підрядних компонентах): Я шкодувала себе, ${ }^{1}$ бо мала на вказівному пальці ранку, ${ }^{2}$ бо відчувала біль, ${ }^{3}$ бо в мене текла червона кров, ${ }^{4}$ бо я жила ${ }^{5}$ (С. Андрухович);

в) емоційний стан людини - об'єктивні обставини, що спричинили цей стан, - психічний стан цієї ж особи $(3,4)$ - об'єктивні обставини, що сприяли появі цього стану: Вона раділа, ${ }^{l}$ бо все було дуже гарно, ${ }^{2}$ бо вона добре почувалася на природi, ${ }^{3}$ бо любила плавати, ${ }^{4}$ бо ій пасував колір $в о д u^{5}$ (С. Андрухович);

г) інтелектуальна дія особи - психічний стан цієї ж особи, який спричинив виконання названої інтелектуальної дії $(2,3)$ - фізичний стан суб'єкта дії, який став причиною інтелектуальної дії, виконуваної у головній частині $(4,5)$ : Цецилія попросила її весь час бути поряд, ${ }^{l}$ бо нареченій було страшенно не по собi, ${ }^{2}$ бо вона знервувалась і хвилювалася, ${ }^{3}$ бо від хвилювання у неї тремтіли руки ${ }^{4}$ і вона раз по раз непритомніла ${ }^{5}$ (С. Андрухович);

д) інтелектуальна дія першого суб'єкта - характеристика фізичного стану другого суб'єкта, який став причиною виконання дії, про яку йдеться у головному складнику: За очі Ізабеллу звали відьмою, ${ }^{l}$ бо вона була надто гарна, ${ }^{2}$ бо вона була надто вдатна, ${ }^{3}$ бо в неї підступна отрута в крові, ${ }^{4}$ бо вона - коханка сина диявола ${ }^{5}$ (Н. Байдаченко).

Засвідчені різновиди смислової організації аналізованих речень вказують на особливу увагу письменників до внутрішнього світу персонажів, до найтонших порухів їхньої душі, виявляють нерозривний зв'язок людини й об'єктивного світу, розкривають найменші впливи навколишнього світу на психоемоційний стан героїв.

Виділені смислові моделі аналізованих речень вдало реалізуються в досліджуваних творах як невід'ємна складова художньої оповіді і вповні виявляють свій текстотвірний потенціал, органічно вплітаючись в загальну тканину твору. Так, Софія Андрухович, уводячи неелементарне складнопідрядне речення з підрядним компонентом причини в мовлення оповідача, зовсім не обтяжує оповідь, а навпаки - надає їй стрімкості і влучності: Я шкодувала себе, бо мала на вказівному пальиі ранку, бо відчувала біль, бо в мене текла червона кров, бо я жила.

Настя Байдаченко, даючи характеристику головній героїні повісті «Перший гріх Ізабелли», також звертається до розглядуваного різновиду складних конструкцій, детально розкриваючи за його допомогою глибинну сутність персонажа: За очі Ізабеллу звали відьмою, бо вона була надто гарна, бо вона була надто вдатна, бо в неї підступна отрута в крові, бо вона - коханка сина диявола.

Ліна Костенко і Марія Матіос, використовуючи розлогу конструкцію складного речення в мовленні оповідача (Після цих одкровень батькова дружина заборонила вмикати телевізор і призначила йому курс лікування, 
бо у нього піднявся тиск і посилилась аритмія (Л. Костенко) й авторському коментарі (Страх $і$ неспокій поперемінно сковував людей, бо прийшов $i$ пішов твердий на вдачу москалик, прийшов і пішов звиклий до муштри й дисципліни румун, знову вступивши край швидкому до дій москалеві (M. Матіос), удаються і до «економії» мовних засобів, пропускаючи сполучник перед другим підрядним компонентом.

Розглянуте дозволяє зробити висновок про те, що, незважаючи на незначну чисельну представленість у названих творах, неелементарні складнопідрядні речення 3 підрядним компонентом причини є яскравим засобом художньої оповіді, що й підтверджують проаналізовані зразки сучасної прози. Логічним продовженням розпочатого в цій статті дослідження неелементарних складнопідрядних речень із підрядним компонентом бачиться виокремлення їх прагматичних типів і визначення комунікативно-прагматичної функції.

\footnotetext{
Література

1. Андрухович С. Літо Мілени : [повість] / Софія Андрухович // Андрухович С. Старі люди. - ІваноФранківськ : Лілея-НВ, 2008. - С. 83-143. - (Першотвір).

2. Андрухович С. Старі люди: [повість] / Софія Андрухович // Андрухович С. Старі люди. - ІваноФранківськ : Лілея-НВ, 2008. - С. 3-82. - (Першотвір).

3. Байдаченко Н. Перший гріх Ізабелли : [повість] / Настя Байдаченко. - К. : Факт, 2006. - 190 с. (Першотвір).

4. Вихованець І. Р. Граматика української мови. Синтаксис : [підручник] / І. Р. Вихованець. - К. : Либідь, 1993. - 368 с.

5. Дудик П. С. Синтаксис української мови : [підручник] / П. С. Дудик, Л. В. Прокопчук. - К. : ВЦ «Академія», 2010. - 382 с.

6. Костенко Л. Записки українського самашедшего : [роман] / Ліна Костенко. - К. : А-БА-БА-ГА-ЛАМА-ГА, 2011. - 416 с. - (Першотвір).

7. Матіос М. Нація : [роман] / Марія Матіос. - Львів : ЛА «Піраміда», 2011. - 256 с. - (Першотвір).

8. Сучасна українська мова : [підручник] / За ред. О. Д. Пономарева. - К. : Либідь, 2008. - 488 с.

9. Тєлєжкіна О. О. Безсполучникові складні речення з компонентом обгрунтування: дис. ... канд. філол. наук : 10.02.01 / Олеся Олександрівна Тєлєжкіна. - Х., 2002. - 180 с.

10. Шульжук К. Ф. Синтаксис української мови : [підручник] / К. Ф. Шульжук. - К. : ВЦ «Академія», 2010. $-407 \mathrm{c}$.
} 